\title{
THEORETICAL CRITERIA FOR ONLINE CONSUMER BEHAVIOUR: WEB- BASED COMMUNICATION EXPOSURE AND INTERNAL PSYCHOLOGICAL BEHAVIOURAL PROCESSES APPROACHES
}

\section{Janette Hanekom}

Department of Communication Science

University of South Africa

hanekj@unisa.ac.za

\section{Rachel Barker}

Department of Communication Science

University of South Africa

barker@unisa.ac.za

\section{ABSTRACT}

Various theories, theoretical viewpoints and models on consumer behaviour stipulate consumers' offline and online behaviour when purchasing a product or using a service. This article deviates from the purchasing perspective and instead 
proposes an information and web-based communication message 'seeking and consumption' perspective. This new perspective is theoretically grounded in two new approaches to online consumer behaviour: the web-based communication exposure and internal psychological behavioural processes approaches; as well as the integration of various theoretical perspectives, approaches, theories and models that address fragments of offline and online consumer behaviour. The research problem is to address the existing limited and fragmented approaches, because existing purchasing perspectives arguably do not provide adequate theoretical criteria to explain online consumer behaviour during interactive information-seeking and consumption activities. Hence, the main aim of this article is to propose new theoretical criteria for online consumer behaviour to address these shortcomings.

Keywords: determinants of consumer behaviour; consumer decision making; consumer information processing and response; information consumption; internal psychological behavioural processes; online consumer behaviour; web-based communication exposure

\section{INTRODUCTION}

Previous consumer behaviour studies by, inter alia, Hoyer and MacInnis (2001), Koufaris (2002), Assael (2004), Blackwell, Miniard and Engel (2006), Gurau (2008) and Hardesty and Bearden (2009) only expound on the activities and behaviour patterns of consumers during the purchasing process. As a result, the research problem of this article is that limited integrated theoretical criteria and literature exist on online consumers' behaviour when searching for, consuming and experiencing online communication, information and content. This article addresses the research problem by proposing theoretical criteria for online consumer behaviour from two new approaches, namely the web-based communication exposure and the internal psychological behavioural processes approaches. These approaches suggest a deviation from existing purchasing perspectives in order to explain online consumer behaviour during interactive information-seeking and consumption activities. The theoretical criteria are further based on, and provide an overview of, existing authors' views on offline and online consumer behaviour from an integrated perspective, as applied to the online context, to promote a better understanding of the theoretical underpinnings of consumer behaviour in the online environment. The article is structured according to five theoretical components which encapsulate the focus areas and provide a foundation for the categorisation of the theoretical criteria. These theoretical components include the contextualisation of consumer behaviour, determinants of offline and online consumer behaviour, online consumer 
information decision-making, consumer information processing and response, and theoretical foundations of consumer behaviour. The article further reports on the first theoretical phase of a study and provides a theoretical underpinning and foundation for a conceptual, integrated theoretical model which will be derived from the theoretical criteria during a subsequent phase.

\section{METHODOLOGY}

Based on the main aim of this article, which is to propose new theoretical criteria for online consumer behaviour, a combination of exploratory and descriptive research within a qualitative research paradigm is followed through an exhaustive literature review. The literature review aims to explore an unknown/new field of study (online consumer behaviour) by 1) providing descriptions of offline and online consumer behaviour from existing perspectives; 2) integrating, summarising and applying the existing perspectives to the new online perspective; and 3) providing in-depth descriptions of online consumer behaviour from the new web-based communication exposure and internal psychological behavioural processes approaches in the form of theoretical criteria. This will be done in line with the following methods: by investigating a body of knowledge; showing previous research and how the current study is linked to it; integrating and summarising what is known in an area of research; demarcating the concepts and theories that are relevant to the particular study; and weighing up the literature and subjecting it to critical appraisal, ideally to lead to a new or interesting perspective. This systematic theoretical analysis, integration and summation of existing offline and online consumer behaviour literature is used to obtain new insights into the phenomenon of online consumer behaviour, to address the lack of information on online consumer behaviour during interactive information-seeking and consumption activities, and to propose theoretical criteria for online consumer behaviour from the web-based communication exposure and internal psychological behavioural processes approaches.

\section{THEORETICAL COMPONENTS OF THE THEORETICAL CRITERIA FOR ONLINE CONSUMER BEHAVIOUR}

The theoretical criteria for online consumer behaviour are categorised according to five components, identified by the authors to provide structure to the discussions below. Furthermore, these were used in the classification of theoretical criteria derived from the exploration, description, summation and integration of the theoretical underpinnings of consumer behaviour from existing offline and online perspectives, and the application of these to the new online perspective (see Figure 1). 


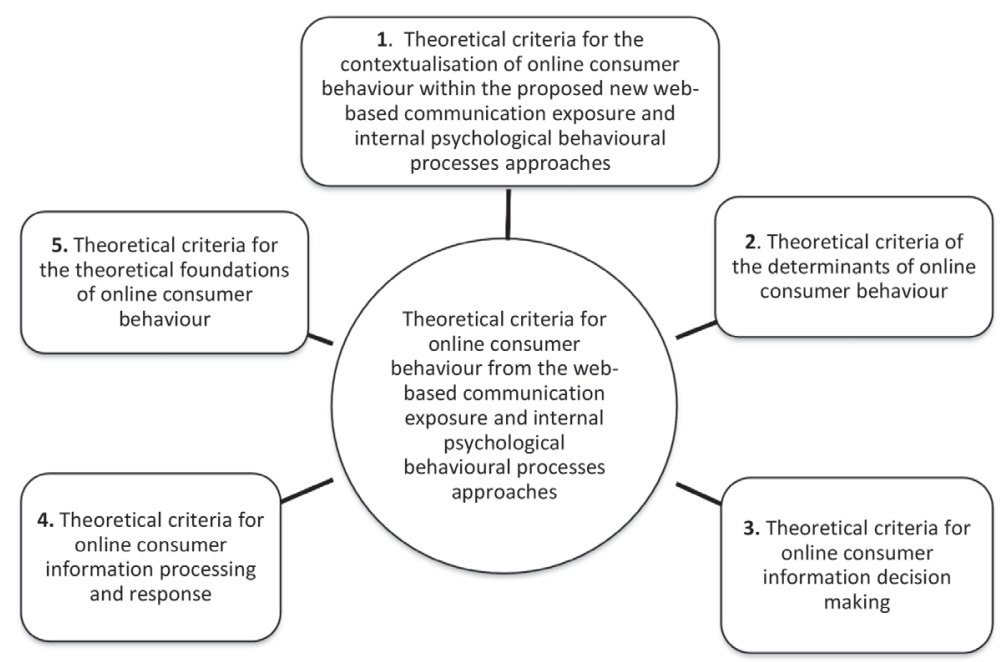

Figure 1: Theoretical components of the theoretical criteria for online consumer behaviour

\section{Theoretical component 1: Contextualisation of consumer behaviour}

In this component, consumer behaviour is contextualised from existing offline and online perspectives to provide a theoretical underpinning for the proposed new contextualisation and definition of, perspective on, and approaches to, online consumer behaviour.

Blackwell, Miniard and Engel $(2006,4)$ define existing offline consumer behaviour as 'activities people undertake when obtaining, consuming and disposing of products and services', while Chaudhuri $(2006,1)$ defines it as 'the study of how and why people consume products and services'. Further definitions by Schiffman and Kanuk (2000), Hoyer and MacInnis $(2001,4)$ and Belch and Belch (2012) explain consumer behaviour in the offline environment as a process that consumers move through when they endeavour to satisfy their needs and desires with products and services. For the purpose of this article, a new definition of offline consumer behaviour is proposed: Consumer behaviour constitutes product acquisition, consumption and disposal activities which are dependent on individual characteristics and environmental factors and motivated by specific needs.

Authors like Hoyer and MacInnis (2001), Constantinides (2004), Koufaris (2004), Demangeot and Broderick (2007), Gurau (2008), Dennis, Merrilees, Jayawardhena and Wright (2009) and Taylor and Strutton (2009) see existing online consumer behaviour as a complete web experience, which suggests a wider 
perspective than the usual offline purchasing perspective. The online environment is different from the offline, where more control is given to the consumer than in the offline environment. Furthermore, direct interaction takes place due to the interactive nature of the online environment. Hence, online consumer behaviour is seen as buying or purchasing behaviour in the online environment, specifically in terms of online consumers searching, browsing, finding, selecting and comparing products.

A new online consumer behaviour perspective is proposed to indicate the move away from consumer behaviour as purchasing behaviour, to considering consumers' behaviour in terms of their search for and consumption of communication experiences, specifically consumers' behaviour in the online context when they are exposed to webbased communication messages. The key contextual differences between the existing offline and online perspectives and the new online consumer behaviour perspective, is the emphasis on communication and informational experiences, specifically the consequence of online consumers' exposure to web-based communication messages to include a complete informational experience. This new perspective focuses on the information-seeking and message consumption actions of online consumers during their search for and consumption of information. Hence a new definition for the new online perspective is proposed: Online consumer behaviour comprises a complete web-based communication experience that manifests in web-based communication exposure and internal psychological behavioural processes leading to cognitive information-processing and response, information decision-making and output processes, determined by internal, external and online factors.

Figure 2 indicates Assael's (2004) existing offline managerial and holistic approaches to consumer behaviour (circles in the centre), as well as the two newly proposed online approaches to consumer behaviour, namely the web-based communication exposure and the internal psychological behavioural processes approaches (circles to the right and left).

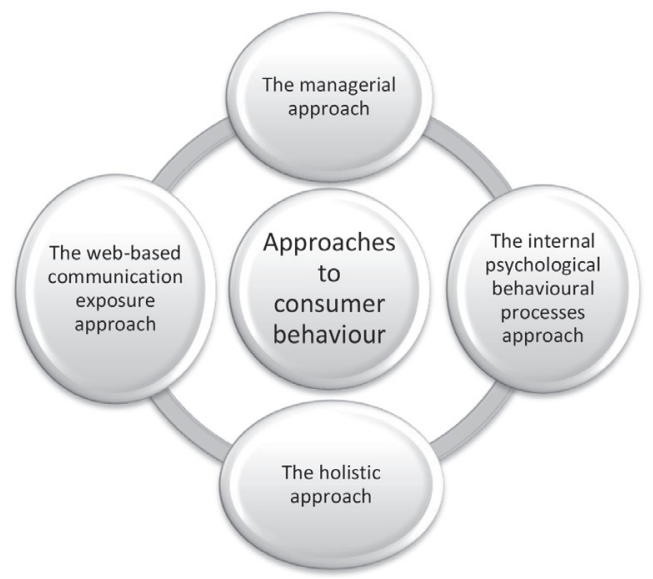

Figure 2: Approaches to consumer behaviour 
A brief overview of these existing offline and new online approaches is summarised in Table 1.

Table 1: $\quad$ Existing approaches and perspectives and proposed new approaches to consumer behaviour

\begin{tabular}{|c|c|c|c|c|c|c|}
\hline $\begin{array}{l}\text { Approaches } \\
\text { and } \\
\text { perspectives }\end{array}$ & $\begin{array}{l}\text { Existing } \\
\text { offline } \\
\text { perspective } \\
\text { on consumer } \\
\text { behaviour }\end{array}$ & $\begin{array}{l}\text { Existing } \\
\text { online } \\
\text { perspective } \\
\text { on consumer } \\
\text { behaviour }\end{array}$ & $\begin{array}{l}\text { The } \\
\text { managerial } \\
\text { approach to } \\
\text { consumer } \\
\text { behaviour } \\
\text { (Assael } \\
2004 \text { ) }\end{array}$ & $\begin{array}{l}\text { The holistic } \\
\text { approach to } \\
\text { consumer } \\
\text { behaviour } \\
\text { (Assael } \\
\text { 2004) }\end{array}$ & $\begin{array}{l}\text { Proposed new } \\
\text { web-based } \\
\text { communication } \\
\text { exposure } \\
\text { approach } \\
\text { to online } \\
\text { consumer } \\
\text { behaviour }\end{array}$ & $\begin{array}{l}\text { Proposed } \\
\text { new internal } \\
\text { psychological } \\
\text { behavioural } \\
\text { processes } \\
\text { approach to } \\
\text { online consumer } \\
\text { behaviour }\end{array}$ \\
\hline \multirow[t]{4}{*}{ Similarities } & $\begin{array}{l}\text { Purchasing of } \\
\text { products }\end{array}$ & $\begin{array}{l}\text { Purchasing } \\
\text { products } \\
\text { online }\end{array}$ & $\begin{array}{l}\text { Product } \\
\text { purchasing } \\
\text { perspective }\end{array}$ & & & \\
\hline & $\begin{array}{l}\text { Influenced by } \\
\text { environmental } \\
\text { factors }\end{array}$ & & $\begin{array}{l}\text { Influenced by } \\
\text { environmental } \\
\text { factors } \\
\text { (macro facet) }\end{array}$ & $\begin{array}{l}\text { Environmen- } \\
\text { tal context }\end{array}$ & $\begin{array}{l}\text { Influenced by } \\
\text { environmental } \\
\text { factors (external } \\
\text { determinants) }\end{array}$ & $\begin{array}{l}\text { Influenced by } \\
\text { environmental } \\
\text { factors (external } \\
\text { determinants) }\end{array}$ \\
\hline & $\begin{array}{l}\text { Influenced } \\
\text { by individual } \\
\text { characteristics }\end{array}$ & $\begin{array}{l}\text { Influenced } \\
\text { by individual } \\
\text { characteristics }\end{array}$ & $\begin{array}{l}\text { Influenced } \\
\text { by individual } \\
\text { differences } \\
\text { (micro facet) }\end{array}$ & & $\begin{array}{l}\text { Influenced } \\
\text { by individual } \\
\text { characteristics } \\
\text { (internal } \\
\text { determinants) }\end{array}$ & $\begin{array}{l}\text { Influenced } \\
\text { by individual } \\
\text { characteristics } \\
\text { (internal } \\
\text { determinants) }\end{array}$ \\
\hline & & Interactivity & & & Interactivity & Interactivity \\
\hline Differences & $\begin{array}{l}\text { Selection, use } \\
\text { and disposal } \\
\text { of products } \\
\text { Consumption } \\
\text { of products }\end{array}$ & $\begin{array}{l}\text { Online } \\
\text { consumer as } \\
\text { a computer } \\
\text { user } \\
\text { Importance of } \\
\text { building trust/ } \\
\text { confidence } \\
\text { Control } \\
\text { Searching, } \\
\text { browsing, } \\
\text { finding, } \\
\text { selecting and } \\
\text { comparing } \\
\text { Evaluating } \\
\text { products }\end{array}$ & $\begin{array}{l}\text { Applied social } \\
\text { science } \\
\text { Micro facet } \\
\text { Macro facet }\end{array}$ & $\begin{array}{l}\text { Pure social } \\
\text { science } \\
\text { Focus on } \\
\text { consumption } \\
\text { experience }\end{array}$ & $\begin{array}{l}\text { Behavioural } \\
\text { processes } \\
\text { of online } \\
\text { consumers } \\
\text { Exposure to } \\
\text { web-based } \\
\text { communication } \\
\text { messages } \\
\text { Experiences } \\
\text { of web-based } \\
\text { communication } \\
\text { messages } \\
\text { Informational } \\
\text { experience } \\
\text { Information- } \\
\text { seeking and } \\
\text { consumption } \\
\text { actions }\end{array}$ & $\begin{array}{l}\text { Internal } \\
\text { psychological } \\
\text { behavioural } \\
\text { processes } \\
\text { Psychological } \\
\text { variables and } \\
\text { constructs } \\
\text { Preinformation } \\
\text { consumer } \\
\text { perception } \\
\text { attributes } \\
\text { Preinformation } \\
\text { consumer } \\
\text { attitudinal attributes } \\
\text { Postinforma-tion } \\
\text { consumer attitudes } \\
\text { Emotion and } \\
\text { reason } \\
\text { Consumer } \\
\text { motivation } \\
\text { Exposure, attention } \\
\text { and perception } \\
\text { Knowledge and } \\
\text { understanding } \\
\text { Attitude formation } \\
\text { Memory and } \\
\text { retrieval }\end{array}$ \\
\hline
\end{tabular}


Because the new theoretical criteria for online consumer behaviour are based on the two new proposed online approaches, they are briefly discussed. First, the web-based communication exposure approach suggests an alternative to the usual purchasing approach, and has been derived from, and is based on, existing theoretical constructs of existing offline and online consumer behaviour theory. Within this approach, the informational perspective is highlighted in that it explains online consumer behaviour as information-seeking and consumption actions as a result of exposure to webbased communication messages. It further contextualises this article in terms of an online consumer behavioural perspective, emphasising online consumer behaviour in terms of exposure to and experience of web-based communication messages. This approach additionally underlines the need to explicate online consumers' information-seeking, information-gathering and information-consumption processes as a result of exposure to web-based communication, pointing to a more cognitive and active environment.

Second, it is argued that the internal psychological behavioural processes approach considers the behavioural processes of online consumers at the internal psychological level. It indicates online consumers' internal psychological behavioural processes when they are exposed to web-based communication messages, as opposed to the usual technical approach focusing on the experience with the website (Martinez-Lopez, Cabal and Gazquez-Abad et al. 2009). This approach considers the psychological elements that explain internal psychological behavioural processes according to various existing psychological theoretical constructs and viewpoints by, inter alia, Schiffman and Kanuk (2000), Hoyer and MacInnis (2001), Koufaris (2002), Assael (2004), Chaudhuri (2006), Wright (2006) and Taylor and Strutton (2009). Table 2 presents a summary of only the relevant key existing offline concepts and viewpoints applicable and applied to the new online consumer behaviour context, which suggests a move away from consumer behaviour as purchasing behaviour, to considering consumers' behaviour in terms of their search for, and consumption of, communication experiences, specifically consumers' behaviour in the online context when they are exposed to web-based communication messages.

Table 2: Theoretical constructs of the internal psychological behavioural processes approach

\begin{tabular}{|l|l|}
\hline $\begin{array}{l}\text { Key theoretical constructs of the } \\
\text { internal psychological behavioural } \\
\text { processes approach }\end{array}$ & Brief explanation \\
\hline $\begin{array}{l}\text { Pre-information consumer perception } \\
\text { attributes }\end{array}$ & $\begin{array}{l}\text { Online consumers base their perceptions during web- } \\
\text { based communication exposure, which they form before } \\
\text { engaging and consuming web-based communication } \\
\text { messages, on the ease with which online messages can } \\
\text { be used, the perceived informational value and perceived } \\
\text { risks. }\end{array}$ \\
\hline
\end{tabular}




\begin{tabular}{|c|c|}
\hline $\begin{array}{l}\text { Key theoretical constructs of the } \\
\text { internal psychological behavioural } \\
\text { processes approach }\end{array}$ & Brief explanation \\
\hline $\begin{array}{l}\text { Pre-information consumer attitudinal } \\
\text { attributes }\end{array}$ & $\begin{array}{l}\text { Before online consumers search for and consume } \\
\text { web-based communication messages, a trusting } \\
\text { relationship between them and the organisation can } \\
\text { be built if trustworthy information that will increase } \\
\text { perceived usefulness and value and reduce perceived } \\
\text { risk, is shared. This will confirm positive attitudes before } \\
\text { information and content search and consumption. }\end{array}$ \\
\hline Postinformational consumer attitudes & $\begin{array}{l}\text { After exposure to web-based communication } \\
\text { messages, online consumers experience either positive } \\
\text { confirmation or negative confirmation, which refers to the } \\
\text { attitudes they form regarding the satisfaction that they } \\
\text { experienced with the online information/messages and } \\
\text { content. }\end{array}$ \\
\hline $\begin{array}{l}\text { Emotion and reason as the motivation } \\
\text { for consumer behaviour }\end{array}$ & $\begin{array}{l}\text { Online consumers' emotion and reason (psychological } \\
\text { constructs) play an important part in the information } \\
\text { processing and response processes of web-based } \\
\text { communication and information and determine their } \\
\text { online behaviour. }\end{array}$ \\
\hline Consumer motivation & $\begin{array}{l}\text { The personal relevance and ability of the online } \\
\text { consumer act as motivators for engaging with web- } \\
\text { based communication messages and information during } \\
\text { web-based communication exposure, search and } \\
\text { consumption. Hence, online consumers are involved in } \\
\text { the online messages and information. }\end{array}$ \\
\hline Exposure, attention and perception & $\begin{array}{l}\text { When web-based communication exposure takes place, } \\
\text { the online consumer comes into contact with the web- } \\
\text { based communication message. The type of mental } \\
\text { activity that the online consumer engages in refers to } \\
\text { attention. This has an influence on the perception of the } \\
\text { web-based communication message. }\end{array}$ \\
\hline Knowledge and understanding & $\begin{array}{l}\text { Online consumers gather knowledge while engaging with } \\
\text { web-based communication messages, hence proceeding } \\
\text { through a process of subjective comprehension. }\end{array}$ \\
\hline Attitude formation & $\begin{array}{l}\text { Online consumers will form an attitude towards the web- } \\
\text { based communication message/interaction, which refers } \\
\text { to the positive or negative manner in which they will } \\
\text { perceive or receive an online message. }\end{array}$ \\
\hline Consumer memory and retrieval & $\begin{array}{l}\text { Online consumers' memory and the their retrieval } \\
\text { processes play a major role during their interactions } \\
\text { in the online environment, especially with regard to } \\
\text { the internal psychological behavioural processes that } \\
\text { they proceed through when exposed to web-based } \\
\text { communication messages and information. }\end{array}$ \\
\hline
\end{tabular}




\section{Theoretical component 2: Determinants of offline and online consumer behaviour}

This section aims to foster an understanding, and provide a brief overview, of the existing theory of the determinants of offline and online consumer behaviour. Several factors/aspects influence the manner in which consumers act and react when they are exposed to offline and online marketing communication messages for the purpose of purchasing a product. In Table 3, existing internal, external and online determinants by authors such as Koufaris (2002), Park and Kim (2003), Constantinides (2004), Blackwell et al. (2006), Chaudhuri (2006), Wells, Moriarty and Burnett (2006), Wright (2006), Chen and Barnes (2007), Choe, Hwang, Kim and Moon (2007), Chu and Lu (2007), Salo and Karjaluoto (2007), Atchariyachanvanich and Sanehara (2008), Grabner-Krauter and Faullant (2008), Ranaweera et al. (2008), Benamati, Fuller, Serva and Barioudi (2009), Taylor and Strutton (2009), Doong, Tai and Wang (2010), Lin, Wang and Hwang (2010), Lu and Zhu (2010), Wang and Liang (2010), Wyer and $\mathrm{Xu}(2010)$ are applied to the new online consumer behaviour context/ perspective of this article.

Table 3: Application of the existing internal, external and online determinants of consumer behaviour to the new online consumer behaviour context of this article

\begin{tabular}{|l|l|l|}
\hline $\begin{array}{l}\text { Internal } \\
\text { determinants } \\
\text { of consumer } \\
\text { behaviour }\end{array}$ & Motivation & $\begin{array}{l}\text { In the online environment, rational, emotional and instinctive } \\
\text { motivations are caused by tension that results from unfulfilled } \\
\text { informational needs. These needs motivate consumers to } \\
\text { search for, consume and engage in web-based communication } \\
\text { messages/information and content. }\end{array}$ \\
\cline { 2 - 3 } & Personality & $\begin{array}{l}\text { Because personality refers to an individual's unique } \\
\text { psychological makeup and characteristics suggesting consistent } \\
\text { and enduring individual difference, it will arguably influence } \\
\text { online consumers' behaviour and experience of web-based } \\
\text { communication messages in the online environment during } \\
\text { exposure. }\end{array}$ \\
\cline { 2 - 3 } & Perception & $\begin{array}{l}\text { Online consumers use selective exposure when they seek out } \\
\text { messages that are relevant to their particular contexts and } \\
\text { then pay selective attention when choosing the most relevant } \\
\text { web-based communication message. Subconsciously, online } \\
\text { consumers may be perceptually defensive and apply perceptual } \\
\text { blocking when they do not wish to be exposed to certain web- } \\
\text { based communication messages and information. }\end{array}$ \\
\cline { 2 - 3 } & $\begin{array}{l}\text { In the online context of this study, incidental learning seldom } \\
\text { takes place since exposure is usually intentional because of the } \\
\text { online consumer's control over the communication encounter } \\
\text { and his/her search for information-intensive communication } \\
\text { messages. }\end{array}$ \\
\hline \multirow{2}{*}{ Learning } & $\begin{array}{l}\text { The process of attitude formation (positive/negative) in the online } \\
\text { environment influences online consumers' online behaviour. }\end{array}$ \\
\hline
\end{tabular}




\begin{tabular}{|c|c|c|}
\hline \multirow{4}{*}{$\begin{array}{l}\text { External } \\
\text { determinants } \\
\text { of consumer } \\
\text { behaviour }\end{array}$} & $\begin{array}{l}\text { Reference } \\
\text { groups and } \\
\text { family }\end{array}$ & $\begin{array}{l}\text { Normative friendship, work, virtual and family reference } \\
\text { groups are social influences that determine or change online } \\
\text { consumers' behaviour in the online environment. }\end{array}$ \\
\hline & Social class & $\begin{array}{l}\text { Because social class is arranged in strata, which explains online } \\
\text { consumers' "positions" in society, it could alter or determine their } \\
\text { online behaviour. }\end{array}$ \\
\hline & Culture & $\begin{array}{l}\text { In the online environment, the evaluation of web-based } \\
\text { communication messages is based on the individual's general } \\
\text { values and norms, which in turn constitute his/her culture. }\end{array}$ \\
\hline & Subculture & $\begin{array}{l}\text { Since subculture is the beliefs, values and norms of a distinct } \\
\text { group of people that functions in the larger context of an existing } \\
\text { culture, it is argued that it could influence online consumers' } \\
\text { behaviour in the online environment. }\end{array}$ \\
\hline \multirow[t]{6}{*}{$\begin{array}{l}\text { Online } \\
\text { determinants } \\
\text { of online } \\
\text { consumer } \\
\text { behaviour }\end{array}$} & Trust & $\begin{array}{l}\text { In existing literature, the concept of trust usually underscores } \\
\text { a purchasing context. However, when applied to the online } \\
\text { consumer information exposure and search context, technology } \\
\text { trust, online trust, competence-based trust and individual trust } \\
\text { should be evident before an online consumer consumes and } \\
\text { interacts with web-based communication messages. }\end{array}$ \\
\hline & $\begin{array}{l}\text { Consumer } \\
\text { familiarity, } \\
\text { technology } \\
\text { acceptance, } \\
\text { prior interaction } \\
\text { and technology } \\
\text { attitude }\end{array}$ & $\begin{array}{l}\text { Online consumers should know and accept the medium they } \\
\text { are utilising. Prior online interactions will reduce complexity } \\
\text { and promote familiarity. Online consumers' technology attitude } \\
\text { determines their cognitive and affective responses to web-based } \\
\text { communication messages. }\end{array}$ \\
\hline & $\begin{array}{l}\text { Functional, } \\
\text { symbolic and } \\
\text { experiential } \\
\text { benefits }\end{array}$ & $\begin{array}{l}\text { Determine whether online consumers accept or decline web- } \\
\text { based communication exposure, consumption and interaction. }\end{array}$ \\
\hline & $\begin{array}{l}\text { The total web } \\
\text { experience }\end{array}$ & $\begin{array}{l}\text { Online consumers' total web experience impacts on their } \\
\text { behaviour when they are exposed to, searching for, consuming } \\
\text { and interacting with web-based communication messages and } \\
\text { information. }\end{array}$ \\
\hline & $\begin{array}{l}\text { Emotional } \\
\text { and cognitive } \\
\text { responses, } \\
\text { perceived } \\
\text { control, } \\
\text { concentration, } \\
\text { attention focus } \\
\text { and message } \\
\text { involvement }\end{array}$ & $\begin{array}{l}\text { An online consumer's emotional state; his/her perceived control } \\
\text { over the online interaction with web-based communication } \\
\text { messages and information; his/her ability to concentrate } \\
\text { and focus attention and involvement in the message itself } \\
\text { determine how he/she will experience and behave in the online } \\
\text { environment. }\end{array}$ \\
\hline & Usability & $\begin{array}{l}\text { Cognitive use of technology when exposure to web-based } \\
\text { communication messages occurs. }\end{array}$ \\
\hline
\end{tabular}


Based on the existing perspectives and their application to the new online consumer behaviour perspective, which suggests a move away from consumer behaviour as purchasing behaviour, to considering consumers' behaviour in terms of their search for and consumption of web-based communication, information and content, the following new definition is proposed: The determinants of online consumer behaviour are controllable and uncontrollable internal, external and online aspects that cognitively and affectively influence and affect online consumer behaviour during the total web experience in the web-based communication exposure and internal psychological behavioural processes approaches.

\section{Theoretical component 3: Online consumer information decision-making}

Consumer decision-making is a complex focal point in the realm of consumer science literature and consumption behaviour which considers decision processes in a purchasing context (Bettman, Luce and Payne 1998; Chaffee and McLeod 1973; Montgomery and Ryans 1973; Solomon 2007; Vohs, Nelson and Rawn 2009; Zellman, Kaye-Blake and Abell 2010). In general, the decision-making process consists of several predictable steps, such as need recognition, information search, evaluation of alternatives and purchase decision. Also, in combination with these steps, consumers make use of different decision strategies such as, amongst others, extended problem solving, limited problem solving, habitual decision making, problem recognition, information search, weighted adding strategy, lexicographic strategy, satisficing, elimination-by-aspects and equal weight utility maximisation (Chrzan 2009; Katsikopoulos and Gigerenzer 2008; Pfeiffer, Duzevik and Rothlauf 2009; Shao, Lye and Rundle-Thiele 2009; Wang and Benbasat 2009; Wang and Liang 2010).

Online consumer decision-making from the proposed web-based communication exposure and internal psychological behavioural processes approaches suggests that consumer decision-making should be conceptualised in terms of web-based communication message exposure and information processing. It is argued that the focus should be on information and message searching as well as consumption and decision making in the online environment. The motivation for proposing this new perspective underlines the move away from a purchasing perspective which restricts the consumer decision-making process to a mere consideration of product attributes and alternatives. From this new perspective, the focus is on information and message alternatives decisions and information decision-making during web-based communication exposure, specifically from an online perspective. This argument is based on the application of existing offline decision-making models and theoretical constructs in a purchasing context identified by, inter alia, Haas (2003), Patwardhan and Ramaprasad (2005) and Roozmand, Ghasem-Aghaee and Hofstede (2011) to the 
new online consumer behaviour perspective. Figure 3 presents the stages and steps which indicate the proposed online consumer information decision-making process, as applied to the web-based communication exposure and internal psychological behavioural processes approaches.
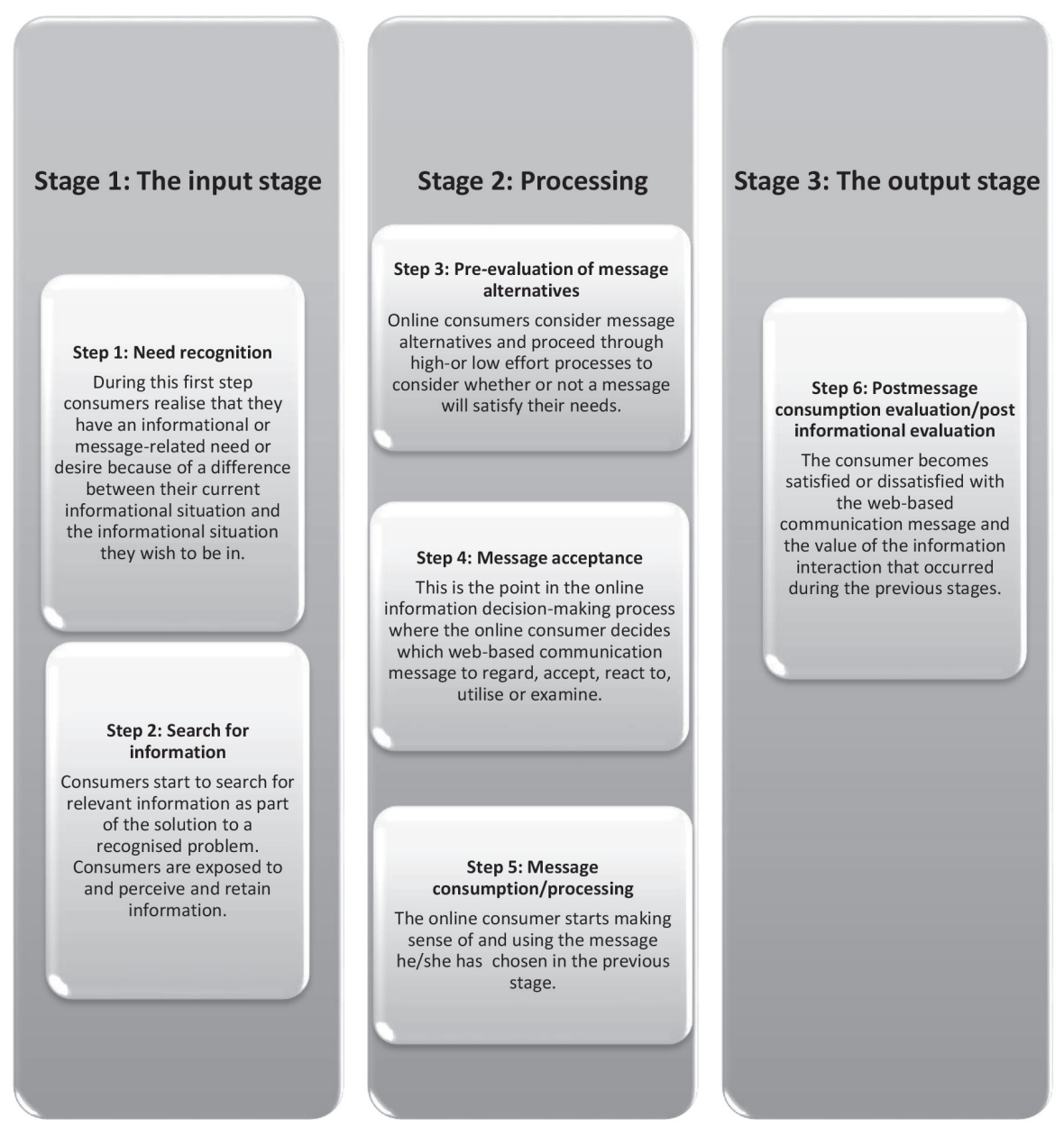

Figure 3: The online consumer information decision-making process 


\section{Theoretical component 4: Consumer information processing and response}

This section provides an indication of how consumers respond to and process information as part of their behaviour when being exposed to and interacting with web-based communication messages. The theoretical criteria for this component are based on the theoretical constructs of existing models, as indicated in Figure 4.

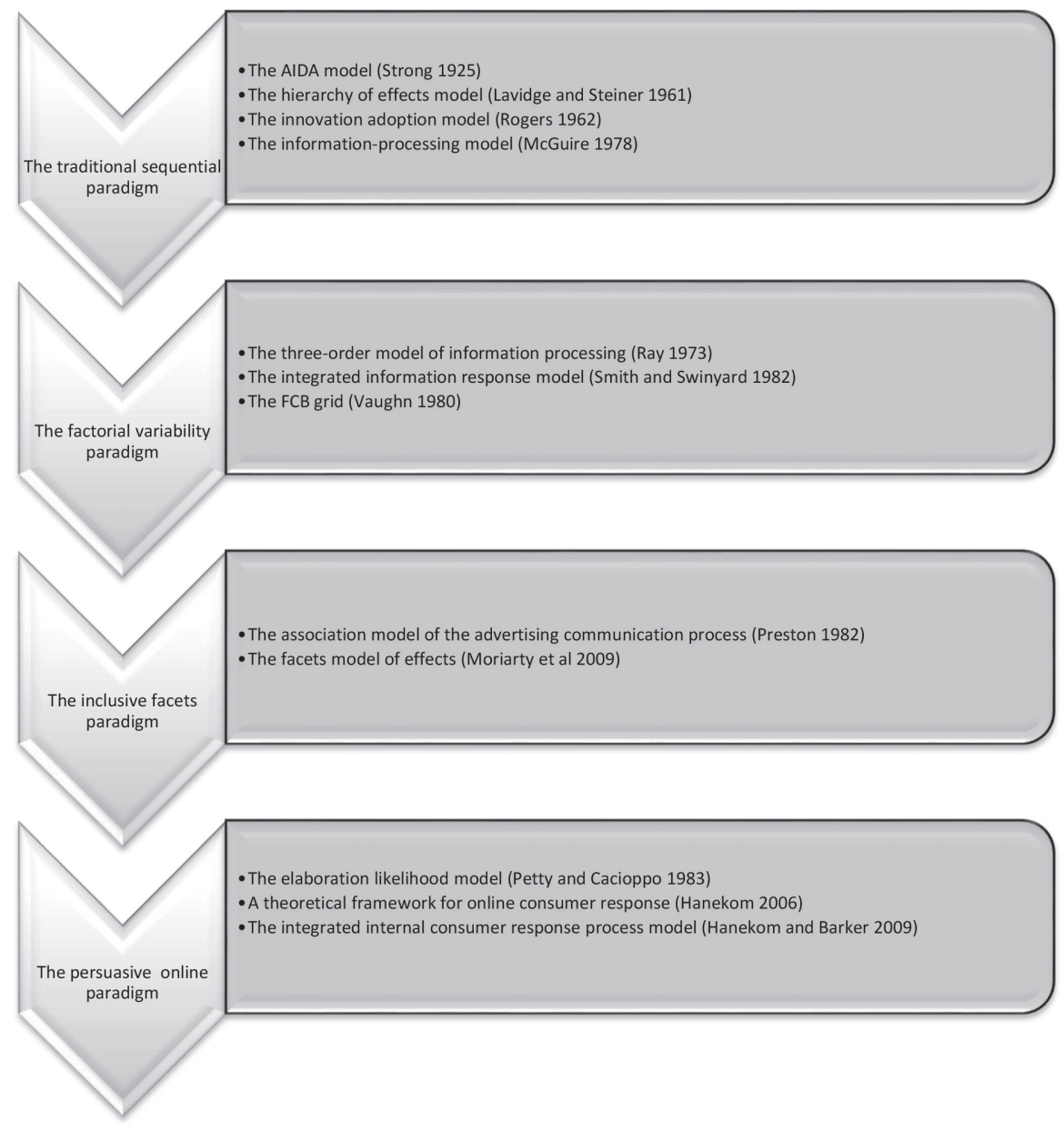

Figure 4: The consumer information-processing and response models and theories 
For the purpose of this article, these models cannot be elaborated on or discussed in-depth, but the main theoretical constructs will be synthesised, integrated, adapted and applied to the web-based communication exposure and internal psychological behavioural processes approaches, and presented as theoretical criteria for consumer information processing and response. To address the aim of this article, it is argued that an emphasis on information theory and a focus on information flow are specifically relevant. In addition, response phases and hierarchical information processing are identified to pinpoint consumers' internal psychological processes during their exposure to information; including cognitive, motor and emotional processes, based on cognitive resources and implying intentionality and controllability.

\section{Theoretical component 5: Theoretical foundations of consumer behaviour}

This section focuses on the existing offline and online theoretical underpinnings of consumer behaviour which are based on specific cognitive psychological and social behavioural predictive theoretical foundations and familiar social psychological concepts (Ajzen and Fishbein 1970). It is proposed that most of the theoretical foundations and key premises on which the theory of consumer behaviour is grounded, are obtained from the theory of reasoned action (Ajzen and Fishbein 1969, 1972, 1974; Fishbein and Ajzen 1973), the theory of planned behaviour (Ajzen 1991; Ajzen and Madden 1986) and the technology acceptance model (TAM) (Davis 1989). The key theoretical premises of these models establish the theoretical grounding for offline and online consumer behaviour. The main theoretical thrusts of the theory of reasoned action explicate attitudinal and normative beliefs as predictors of behavioural intentions and most human behaviour. This is echoed by the major theoretical implications of the theory of planned behaviour as the incorporation of perceived control, attitudes and subjective norms over behavioural achievement as determinants of individuals' intentions and behaviour. The main theoretical thrusts of the TAM predict and explain the use of new technology and information systems by means of two theoretical constructs, perceived usefulness and perceived ease of use, as fundamental determinants of system use.

\section{THEORETICAL CRITERIA FOR ONLINE CONSUMER BEHAVIOUR}

This section addresses the research problem of the article, namely to develop theoretical criteria for online consumer behaviour from the web-based communication exposure and internal psychological behavioural processes approaches. The theoretical criteria provide a new structure, theoretical underpinning and foundation to online consumer behaviour which differ from the existing purchasing perspectives 
and are in line with the new proposed web-based communication exposure and internal psychological behavioural processes approaches.

Figures 5-9 provide a summary of the main theoretical criteria for each theoretical component of online consumer behaviour. Although only the main authors have been indicated previously, the theoretical criteria, summaries, interpretations and critical analyses below are derived and adapted from all existing literature on offline and online consumer behaviour. These theoretical criteria have been summarised in Figures 5-9 and are explained below, but in-depth discussions have not been provided due to limited space.

\section{Theoretical criteria for theoretical component 1: Contextualisation of consumer behaviour}

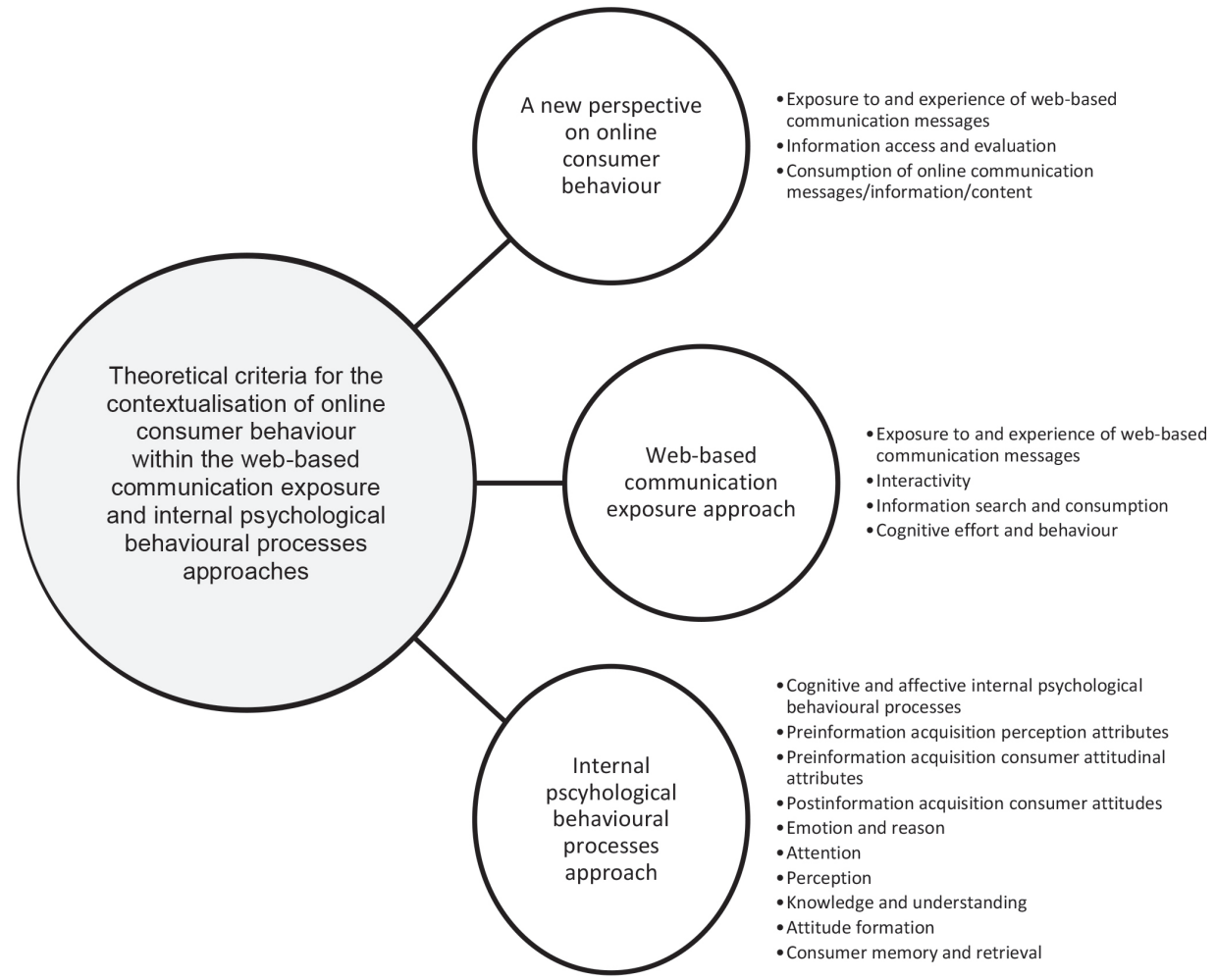

Figure 5: Theoretical criteria for the contextualisation of online consumer behaviour within the web-based communication exposure and internal psychological behavioural processes approaches 
Figure 5 is a summary of the theoretical criteria for the contextualisation of online consumer behaviour within the web-based communication exposure and internal psychological behavioural processes approaches. In contrast to existing authors' consideration of offline and online consumer behaviour from a purchasing perspective, the theoretical criteria emphasise the new online perspective of consumers' exposure and experience of web-based communication messages and their subsequent psychological behavioural processes. Hence, theoretical criteria such as exposure, experience, information access, evaluation and consumption are relevant. As a theoretical foundation, existing offline and online consumer behaviour theory are applied to the new online context to include theoretical criteria for the web-based communication exposure approach, such as interactivity, information search, cognitive effort and behaviour. The need to understand consumers' cognitive and affective psychological processes underwrites the development of the internal psychological behavioural processes approach. This approach is illustrated by theoretical criteria such as pre-information acquisition perception attributes, preinformation acquisition consumer attitudinal attributes, post-information acquisition consumer attitudes, emotion and reason, attention, perception, knowledge and understanding, attitude formation and consumer memory and retrieval.

\section{Theoretical criteria for theoretical component 2: Determinants of offline and online consumer behaviour}

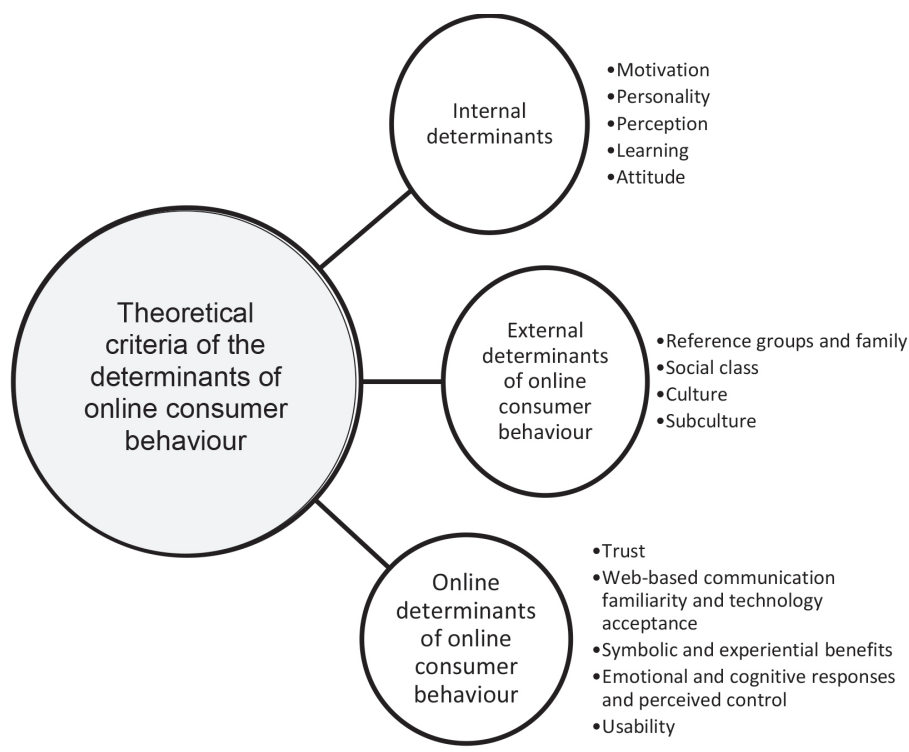

Figure 6: Theoretical criteria of the determinants of online consumer behaviour 
Figure 6 offers a summary of the theoretical criteria of the determinants of online consumer behaviour, which can be described as controllable and uncontrollable internal, external and online aspects that cognitively and affectively influence and affect online consumer behaviour during exposure to, and consumption of, web-based communication messages and the subsequent psychological behavioural processes. More specifically, internal determinants are regarded as basic psychological determinants and comprise theoretical criteria such as motivation, personality, perception, learning and attitude. External determinants refer to social and cultural concepts that influence online consumers' behaviour and include theoretical criteria such as reference groups and family, social class, culture and subculture. Theoretical criteria such as trust, web-based communication familiarity and technology acceptance, symbolic and experiential benefits, emotional and cognitive responses, and perceived control and usability are included as online determinants of online consumer behaviour.

\section{Theoretical criteria for theoretical component 3: Online consumer information decision making}

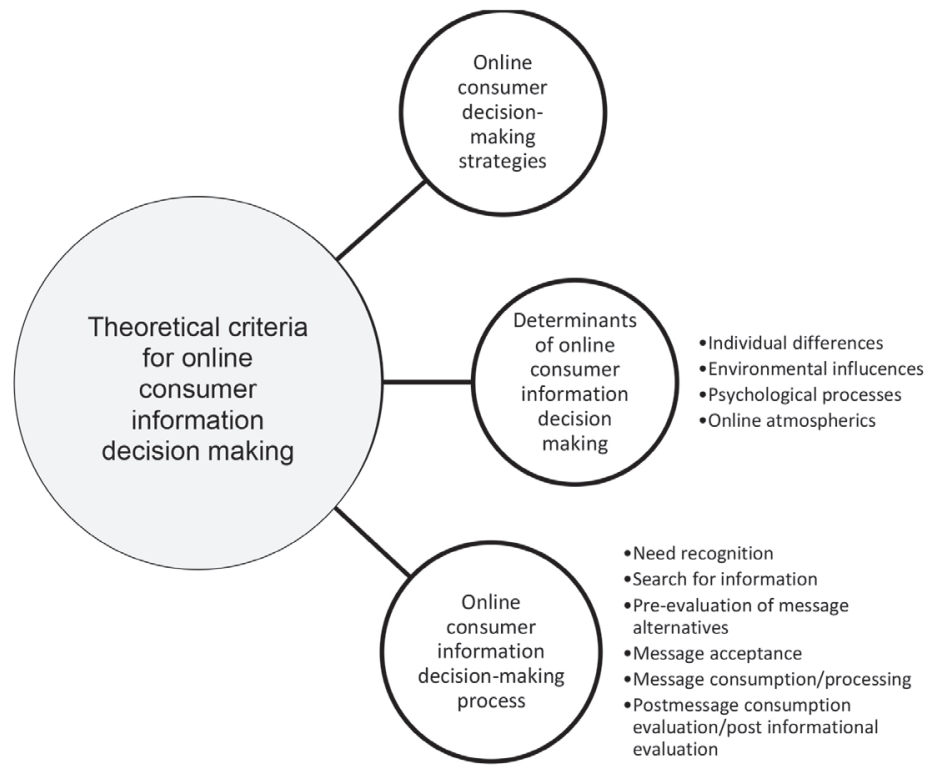

Figure 7: Theoretical criteria for online consumer information decision making

For the purpose of proposing theoretical criteria for online consumer information decision making in terms of the web-based communication exposure and internal 
psychological behavioural processes approaches (see Figure 7), online consumer information decision making is deemed to illustrate consumers' decision-making processes in terms of web-based communication message exposure and information processing before information and message consumption occurs. For the purpose of establishing theoretical criteria, existing decision strategies are applied to the new online context to include criteria such as extended problem solving, limited problem solving, habitual decision making, problem recognition, information search, satisficing, affective attribute processing, elimination heuristics and classic maximisation. Theoretical criteria for the determinants of online consumer information decision making include individual differences, environmental influences, psychological processes and online atmospherics. If the theoretical criteria for the online consumer information decision-making process are applied to the new context, it will include need recognition, search for information, preevaluation of message alternatives, message acceptance, message consumption/ processing, post-message consumption evaluation/post-informational evaluation.

\section{Theoretical criteria for theoretical component 4: Online consumer information processing and response}

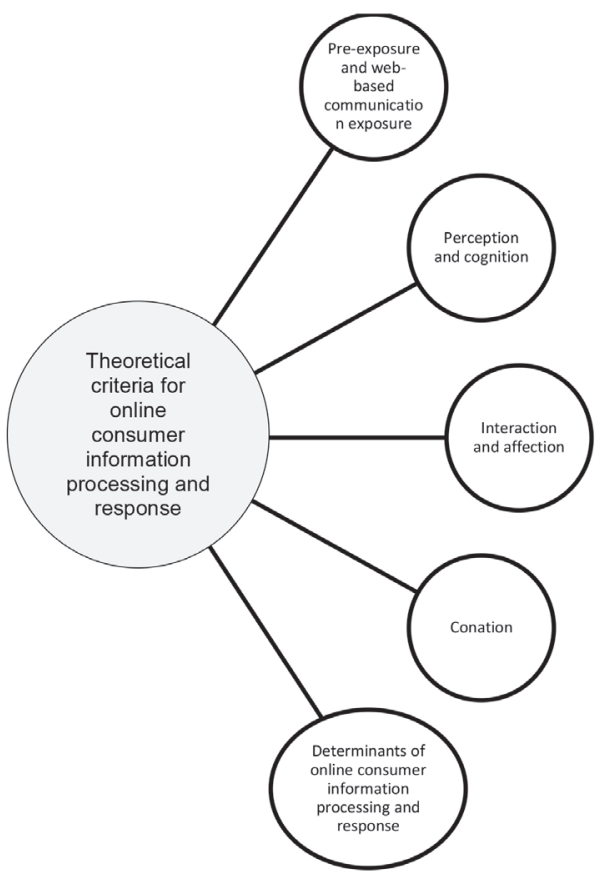

Figure 8: Theoretical criteria for online consumer information processing and response 
The theoretical criteria for online consumer information processing and response (Figure 8) provide a deeper understanding of how online consumers respond to and process information. For the purpose of this section, the theoretical criteria are organised into broad categories that indicate online consumers' information processing and response progression during their exposure to, and experience of, web-based communication messages. This encompasses all the relevant phases, stages and theoretical explanations that are indicated in the existing offline and online models and theories of consumer information processing and response. The theoretical criteria include pre-exposure, web-based communication exposure, perception, cognition, interaction, affection and conation.

\section{Theoretical criteria for theoretical component 5: Theoretical foundations of online consumer behaviour}

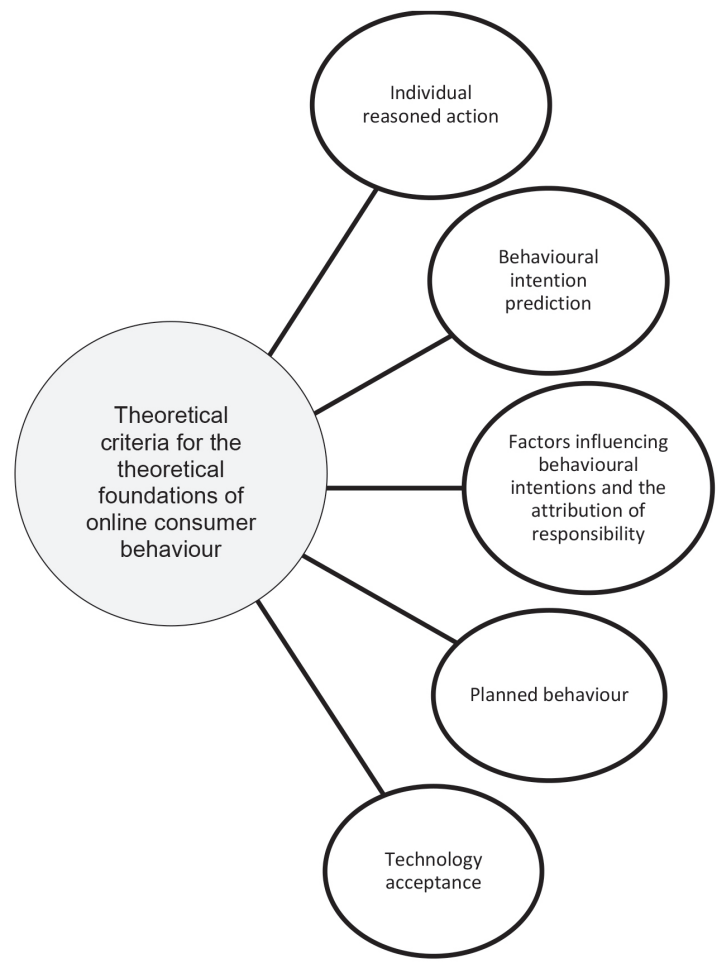

Figure 9: Theoretical criteria for the theoretical foundations of online consumer behaviour 
The main theoretical premises and foundations on which the theory of consumer behaviour is grounded, and from which the theoretical criteria in Figure 9 are derived, are the theory of reasoned action, that of planned behaviour and the TAM. Certain of the major theoretical concepts can be applied to the new online context of this article, and are identified as theoretical criteria. Individual reasoned action is a theoretical concept that indicates motivation in predicting behavioural intention and behaviour in social situations. Behavioural intention prediction indicates social behaviour in terms of individuals' behaviour resulting from behavioural intention, determined by attitude towards the act and by beliefs about what the other individual expects. Furthermore, an individual's attitude is determined by the perceived consequences and the value thereof to that specific individual, hence describing the factors influencing behavioural intentions and the attribution of responsibility. The theoretical criteria for planned behaviour predict social human behaviour by incorporating perceived control, attitudes and subjective norms over behavioural achievement as determinants of an individual's intentions and behaviour. These criteria include perceived behavioural control or cognitive self-regulation, skills, abilities, knowledge and informational influences. Technology acceptance indicates theoretical criteria such as the use of new technology and behavioural intention as being determined by perceived usefulness and perceived ease of use.

\section{LIMITATIONS AND RECOMMENDATIONS FOR FUTURE RESEARCH}

The main limitation of this article is that it is exploratory in nature, and the specific perspectives and approaches used might be considered a somewhat restricted view of consumer behaviour. However, these approaches propose a move away from existing purchasing approaches to address a dearth in the literature by focusing on an information and web-based communication message 'seeking and consumption' perspective. Future studies might consider alternative perspectives and approaches to online consumer behaviour as well. In addition, it is recommended that a model for online consumer behaviour be developed to indicate the sequential behavioural processes of online consumers' behaviour from the web-based communication exposure and internal psychological behavioural processes approaches. The theoretical criteria could serve as a theoretical foundation for the development of a new model. In addition, this model could address the gap in the literature with regard to online consumers' internal psychological processes, where consumers are exposed to web-based communication messages and proceed through the complete web-based communication experience. 


\section{CONCLUSION}

This article addressed the research problem that limited integrated theoretical criteria and literature exist on online consumers' behaviour when searching for, consuming and experiencing online communication, information and content. Hence, theoretical criteria for online consumer behaviour from the web-based communication exposure and internal psychological behavioural processes approaches were proposed, which suggest a deviation from the focus on existing purchasing perspectives in the literature. The theoretical criteria were based on five theoretical components identified by the authors to structure the article, including a contextualisation of online consumer behaviour within the proposed new web-based communication exposure and internal psychological behavioural processes approaches; the determinants of online consumer behaviour; online consumer information decision making; online consumer information processing and response; and the theoretical foundations of online consumer behaviour. The article explored an unknown/new field of study (online consumer behaviour) by providing descriptions of offline and online consumer behaviour from existing perspectives. Based on these, existing perspectives were integrated, summarised and applied to the new online perspective proposed in the article. Furthermore, in-depth descriptions of online consumer behaviour from the new web-based communication exposure and internal psychological behavioural processes approaches in the form of theoretical criteria were provided. It is argued that the theoretical criteria promote a better understanding of the theoretical underpinnings of consumer behaviour in the online environment, according to the proposed new approaches and the new online perspective. The need for this new online consumer behaviour perspective is supported by Xiang, Magnini and Fesenmaier $(2015,244)$, who point out that "the Internet is now comprised of a huge amount of information which essentially represents the "external memory" for many people', which underlies the importance of this article and the significance of the proposed information and web-based communication message search and consumption perspectives.

\section{REFERENCES}

Ajzen, I. 1991. The theory of planned behaviour. Organizational Behavior and Human Decision Processes 50: 179-211.

Ajzen, I. and M. Fishbein. 1969. The prediction of behavioural intentions in a choice situation. Journal of Experimental Social Psychology 5: 400-416.

Ajzen, I. and M. Fishbein. 1970. The prediction of behaviour from attitudinal and normative variables. Journal of Experimental Social Psychology 6: 466-487.

Ajzen, I. and M. Fishbein. 1972. Attitudes and normative beliefs as factors influencing behavioural intentions. Journal of Personality and Social Psychology 21(1): 1-9. 
Ajzen, I. and M. Fishbein. 1974. Factors influencing intentions and the intention-behavior relation. Human Relations 27(1): 1-15.

Ajzen, I. and T.J. Madden. 1986. Prediction of goal-directed behavior: Attitudes, intentions, and perceived behavioural control. Journal of Experimental Social Psychology 22: 453-474.

Assael, H. 2004. Consumer behavior: A strategic approach. New York: Houghton Mifflin.

Atchariyachanvanich, K. and N. Sonehara. 2008. Trust perception in Internet shopping: Comparative study of customers in Japan and South Korea. $10^{\text {th }}$ International Conference on Electronic Commerce (ICEC), Innsbruck, Austria.

Belch, G.E. and M.A. Belch. 2012. Advertising and promotion: An integrated marketing communications perspective, $9^{\text {th }}$ edition. New York: McGraw-Hill Irwin.

Benamati, J., M.A. Fuller, A. Serva and J. Baroudi. 2009. Clarifying the integration of trust and TAM in E-commerce environments: Implications for systems design and management. IEEE Transactions on Engineering Management 59(3).

Bettman, J.R., M.F. Luce and J.W. Payne. 1998. Constructive consumer choice processes. Journal of Consumer Research 25(3): 187-217.

Blackwell, R.D., P.W. Miniard and J.F. Engel. 2006. Consumer behavior, $10^{\text {th }}$ edition. Singapore: Thomson South-Western.

Chaffee, S.H. and J.M. McLeod. 1973. Consumer decisions and information use in consumer behavior: Theoretical sources. In Consumer behaviour, ed. S. Ward, 385-415. Englewood Cliffs, NJ: Prentice-Hall.

Chaudhuri, A. 2006. Emotion and reason in consumer behavior. New York: ButterworthHeinemann, Elsevier.

Chen, Y-H. and S. Barnes. 2007. Initial trust and online buyer behavior. Industrial Management and Data Systems 107(1): 21-36.

Choe, Y.C., D-R. Hwang, M. Kim and J. Moon. 2007. Product heterogeneity: Moderating effect on online consumer behavior. Proceedings of the $40^{\text {th }}$ Hawaii International Conference on System Sciences, January.

Chrzan, K. 2009. Decisions: A lexicographic choice model offers benefits for brand tracking research. Marketing Research (Summer): 13-17.

Chu, C-W. and H-P. Lu. 2007. Factors influencing online music purchase intention in Taiwan. Internet Research 17(2): 139-155.

Constantinides, E. 2004. Influencing the online consumer's behavior: The web experience. Internet Research 14(2): 111-126.

Davis, F.D. 1989. Perceived usefulness, perceived ease of use, and user acceptance of information technology. MIS Quarterly 13(3): 319-340.

Demangeot, C. and A.J. Broderick. 2007. Conceptualising consumer behaviour in online shopping environments. International Journal of Retail and Distribution Management 35(11): 878894.

Dennis, C., B. Merrilees, C. Jayawardhena and L.T. Wright. 2009. E-consumer behaviour. European Journal of Marketing 43(9/10): 1121-1139. 
Doong, H-S., C-F. Tai and H-C. Wang. 2010. Determinants of consumers' e-loyalty: A crosschannel perspective. Proceedings of the $43^{\text {rd }}$ Hawaii International Conference on System Sciences, January 5-8.

Fishbein, M. and I. Ajzen. 1973. Attribution of responsibility: A theoretical note. Journal of Experimental Social Psychology 9: 148-153.

Grabner-Krauter, S. and R. Faullant. 2008. Consumer acceptance of Internet banking: The influence of Internet trust. International Journal of Bank Marketing 26(7): 483-504.

Gurau, C. 2008. Integrated online marketing communication: Implementation and management. Journal of Communication Management 12(2): 169-184.

Haas, S.W. 2003. Improving the search environment: Informed decision making in the search for statistical information. Journal of the American Society for Information Science and Technology 54(8): 782-797.

Hanekom, J. 2006. A theoretical framework for the online consumer response process. Master's dissertation, University of South Africa, Pretoria.

Hanekom, J. and R. Barker. 2009. The internal consumer response process: Towards an integrated conceptual model. Communicatio 35(1): 138-164.

Hardesty, D.M. and W.O. Bearden. 2009. Consumer behavior and retailing. Journal of Retailing 85(3): 239-244.

Hoyer, W.D. and D.J. MacInnis. 2001. Consumer behavior, $2^{\text {nd }}$ edition. Boston: Houghton Mifflin.

Katsikopoulos, K.V. and G. Gigerenzer. 2008. One-reason decision-making: Modeling violations of expected utility theory. Journal of Risk Uncertainty 37: 35-56.

Koufaris, M. 2002. Applying the technology acceptance model and flow theory to online consumer behavior. Information Systems Research 13(2): 205-223.

Lavidge, R.J. and G.A. Steiner. 1961. A model for predictive measurements of advertising effectiveness. Journal of Marketing 25(6): 59-62.

Lin, C-F. and H-F. Wang. 2008. A decision-making process model of young online shoppers. CyberPsychology and Behavior 11(6): 759-761.

Lu, C-T. and D-S. Zhu. 2010. The study on the determinants of the online consumers' intention to return. $9^{\text {th }}$ IEEE/ACIS International Conference on Computer and Information Science, Yamagata, August 18-20.

Martinez-Lopez, F.J., C.C. Cabal, J.C. Gazquez-Abad and I. Rodriquez-Ardura. 2009. A theoretical approximation to the psychological aspects related to the consumer's adoption and use of a website recommendation system. The $28^{\text {th }}$ North American Fuzzy Information Processing Society Annual Conference (NAFIPS 2009), Cincinnati, Ohio, June 14-17.

McGuire, W.J. 1978. An information processing model of advertising effectiveness. In Behavioural and management science in marketing, ed. H.J. Davis and A.J. Silk, 156-180. New York: Ronald Press.

Montgomery, D.B. and A.B. Ryans. 1973. Stochastic models of consumer choice behavior. In Consumer behavior: Theoretical sources, ed. S. Ward, 494-576. Englewood Cliffs, NJ: Prentice-Hall.

Moriarty, S., N. Mitchell and W. Wells. 2009. Advertising: Principles and practices, $8^{\text {th }}$ edition. Upper Saddle River, NJ: Prentice-Hall Pearson. 
Park, C-H. and Y-G. Kim. 2003. Identifying key factors affecting consumer purchase behavior in an online shopping context. International Journal of Retail and Distribution Management 31(1): 16-29.

Patwardhan, P. and J. Ramaprasad. 2005. A rational model of online consumer decision making. Journal of Interactive Advertising 6(1): 3-18.

Petty, R.E. and J.T. Cacioppo. 1983. Central and peripheral routes to persuasion: Application to advertising. In Advertising and consumer psychology, ed. L. Percy and A. Woodside, 3-23. Lexington, MA: Lexington Books.

Pfeiffer, J., D. Duzevik and F. Rothlauf. 2009. A genetic algorithm for analyzing choice behavior with mixed decision strategies. GECCO 2009, Montreal, Quebec, Canada, July 8-12.

Preston, I.L. 1982. The association model of the advertising communication process. Journal of Advertising 11(2): 3-15.

Ranaweera, C., H. Bansal and G. McDougall. 2008. Website satisfaction and purchase intentions. Managing Service Quality 18(4): 329-348.

Ray, M.L. 1973. Marketing communication and the hierarchy of effects. In New models for mass communication research, ed. P. Clarke, 147-176. Beverly Hills, CA: Sage.

Rogers, E.M. 1962. Diffusion of innovations. New York: The Free Press of Glencoe.

Roozmand, O., N. Ghasem-Aghaee and G.J. Hofstede. 2011. Agent-based modeling of consumer decision-making process based on power, distance and personality. Knowledge-Based Systems 24(7): 1075-1095.

Salo, J. and H. Karjaluoto. 2007. A conceptual model of trust in the online environment. Online Information Review 31(5): 604-621.

Schiffman, L.G. and L.L. Kanuk. 2000. Consumer behavior, $7^{\text {th }}$ edition. Upper Saddle River, NJ: Prentice Hall.

Shao, W., A. Lye and S. Rundle-Thiele. 2009. Different strokes for different folks: A method to accommodate decision-making heterogeneity. Journal of Retailing and Consumer Services. doi:10.1016/j.jretconser (accessed August 4, 2009).

Smith, R.E. and W.R. Swinyard. 1982. Information response models: An integrated approach. Journal of Marketing 46 (Winter): 81-93.

Solomon, M.R. 2007. Consumer behavior: Buying, having, and being, $7^{\text {th }}$ edition. Upper Saddle River, NJ: Prentice Hall.

Strong, E.K. 1925. The psychology of selling and advertising. New York: McGraw-Hill.

Taylor, D.G. and D. Strutton. 2009. Has e-marketing come of age? Modeling historical influences on post-adoption era Internet consumer behaviors. Journal of Business Research. DOI:10.1016/j.jbusres (accessed January 18, 2009).

Vaughn, R. 1980. How advertising works: A planning model ... putting it all together. Journal of Advertising Research 20(5): 27-33.

Vohs, K.D., N. Nelson and C. Rawn. 2009. Why do choices tax self-regulatory resources? Three tests of candidates to explain decision fatigue. Advance in Consumer Research 36: 172-176.

Wang, W.W. and I. Benbasat. 2009. Interactive decision aids for consumer decision making in e-commerce: The influence of perceived strategy restrictiveness. MIS Quarterly 33(2): 293320. 
Wang, W-H. and C-J. Liang. 2010. Consumer behavior of the information services industry in Taiwan: Conceptual framework and hypotheses development. Measuring Business Excellence 14(2): 12-21.

Wells, W., S. Moriarty and J. Burnett. 2006. Advertising principles and practice, 7th edition. Upper Saddle River, NJ: Pearson Prentice-Hall.

Wright, R. 2006. Consumer behaviour. London: Thomson.

Wyer Jr., R.S. and A.J. Xu. 2010. The role of behavioral mind-sets in goal-directed activity: Conceptual underpinnings and empirical evidence. Journal of Consumer Psychology 20(2): $107-125$.

Xiang, Z., V.P. Magnini and D.R. Fesenmaier. 2015. Information technology and consumer behavior in travel and tourism: Insights from travel planning using the Internet. Journal of Retailing and Consumer Services 22: 244-249.

Zellman, E., W. Kaye-Blake and W. Abell. 2010. Identifying consumer decision-making strategies using alternative methods. Qualitative Market Research: An International Journal 13(3): 271-286. 